\title{
STUDI KOMPARASI KEPRIBADIAN GURU AGAMA ISLAM DAN GURU PKN DENGAN GURU UMUM DALAM PEMBINAAN CHARACTER BUILDING BERBASIS PENDIDIKAN NILAI-NILAI ISLAMI DI SMA ISLAMIC VILLAGE, TANGERANG, BANTEN
}

\author{
Fathimah Nur Shabrina
}

Alumni Program Studi Pendidikan Agama Islam, FIAI, Universitas Islam Indonesia fathimah.nurshabrina@gmail.com

\section{ABSTRACT}

Nowadays, we are witnessing many criminal acts related to students and teachers that indicates the failure of education. It is a matter of concern because in the era of rapid technological development, the virtues of morality, character, morals, and dignity are important for the future of the nation. Therefore, in order to scrutiny the cause of the problem above, the researcher conducted a study on the competence of Islamic education teachers and teachers of civics and comparing it with general teachers. The purpose of this study was to determine significant different between the personality of Islamic education teachers and civics education teachers with other teachers on the instilling of character building education-based Islamic values.

The research approach used in this research is quantitative research. The type of research is field research. The location of this research was conducted at SMA Islamic Village, Tangerang, Banten. The subjects of this study are 36 respondents of Islamic education, civics, and general teachers. The data were collected through questionnaire and were analyzed by T-Test (Independent Sample Test) on SPSS version 24.0 for windows.

The results showed us that there is no significant difference between the personality of Islamic education and civics teachers (X1) and the general teachers' personality (X2). This result is concluded from the result of the T-Test (Independent Sample Test) that the results of 2-tailed (Sig. 2-tailed) significance value of 0.495 and 0.485 is greater than probability 0.05 ( $p=0.495$ and $0.485>0.05)$. The results are also reinforced by the absence of the mean difference of two samples, that is $X 1=6.578$ and $X 2=7.025$. 


\title{
Fathimah Nur Shabrina
}

Keywords: Teachers'Personality, Character Building, Islamic Values.

\begin{abstract}
ABSTRAK
Hari-hari ini, kita banyak melihat kasus kriminal yang dilakukan oleh pelajar maupun guru sekolah. Fenomena ini adalah permasalahan yang harus diperhatikan, mengingat dalam era perkembangan teknologi, masalah moralitas, nilai-nilai, martabat kemanusiaan adalah landasan penting bagi masa depan bangsa. Atas dasar fenomena tersebut, penulis tergerak untuk meneliti kompetensi guru agama dan PKN serta membandingkannya dengan guru umum, untuk mengetahui ada atau tidaknya perbedaan yang signifikan antara keduanya. Hal ini penting mengingat urgensi guru agama dan PKN dalam pembentukan karakter siswa.

Pendekatan penelitian yang digunakan dalam penelitian ini adalah kuantitatif. Jenis penelitian ini adalah penelitian lapangan (field research). Lokasi penelitian ini dilakukan di SMA Islamic Village, Tangerang, Banten. Subjek penelitian ini adalah guru pengampu pelajaran Agama Islam, guru PKn, dan guru umum, yang berjumlah 36 responden. Metode pengumpulan data dalam penelitian ini adalah kuisioner. Metode analisis data ini menggunakan Uji T-Test (Independent Sample Test) pada SPSS versi 24.0 for windows.
\end{abstract}

Temuan hasil penelitian ini menunjukkan bahwa tidak ada perbedaan yang signifikan antara kedua sampel, yaitu kompetensi kepribadian guru agama Islam dan PKn $\left(\mathrm{X}_{1}\right)$ dan kompetensi kepribadian guru umum $\left(\mathrm{X}_{2}\right)$. Hal ini dibuktikan dari hasil analisis yang menggunakan Uji T-Test (Independent Sample Test) bahwa hasil nilai signifikansi 2-tailed (Sig. 2-tailed) sebesar 0,495 dan 0,485 lebih besar dari probabilitas 0.05 ( $\mathrm{p}=0,495$ dan 0,485 $>0,05)$. Hasil tersebut dikuatkan juga oleh tidak adanya perbedaan mean kedua sampel, yaitu $X_{1}=6.578$ dan $X_{2}=7,025$.

Kata Kunci: Kepribadian Guru, Character Building, Nilai-Nilai Islami. 


\section{Studi Komparasi Kepribadian ...

\section{PENDAHULUAN}

Tujuan dari pendidikan, seperti dikutip Abdurrahman, adalah transfer pengetahuan dan nilai (knowledge and values) (2007:3). Menurut UU No. 20 tahun 2003 seperti dikutip oleh Hasbullah, "pendidikan adalah usaha sadar dan terencana untuk mewujudkan suasana belajar dan proses pembelajaran agar peserta didik secara aktif mengembangkan potensi dirinya untuk memiliki kekuatan spiritualkeagamaan, pengendalian diri, kepribadian, kecerdasan, akhlak mulia, serta keterampilan yang diperlakukan dirinya, masyarakat, bangsa, dan negara (2008: 4).

Pendidikan termasuk di dalamnya sistem persekolahan, menurut Fuad Yusuf, adalah institusi yang penting peranannya dalam hal pengembangan bidang intelektualitas dan moral 92008: 43). Berdasarkan UU SISDIKNAS Nomor 2 Tahun 1989, Pasal 4 yang dikutip oleh Alisuf Sabri, pendidikan nasional bertujuan mencerdaskan kehidupan bangsa dan mengembangkan manusia seutuhnya, yaitu manusia yang beriman dan bertaqwa terhadap Tuhan Yang Maha Esa dan berbudi pekerti luhur, memiliki pengetahuan dan keterampilan, kesehatan jasmani dan rohani, kepribadian yang mantap dan mandiri serta tanggung jawab kemasyarakatan dan kebangsaan.” (2005: 71-72).

Sejalan dengan tujuan pendidikan nasional, pendidikan Islam merupakan aktivitas pendidikan yang diselenggarakan atau didirikan dengan hasrat dan niat untuk mengejawantahkan ajaran dan nilai-nilai Islam (Muhaimin, 2009: 14). Kriteria atau sosok guru yang ideal, dalam perspektif Islam tidak lepas dari sosok Nabi Muhammad Saw. Beliau merupakan sosok pendidik teladan yang dijadikan tolak ukur ideal untuk seorang guru agama Islam. Hal ini telah dijelaskan dalam Al-Qur'an pada ayat-ayat berikut ini:

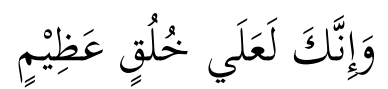

Artinya: "Dan sesungguhnya kamu benar-benar berada diatas budi pekerti yang agung." (Al-Qalam: 4).

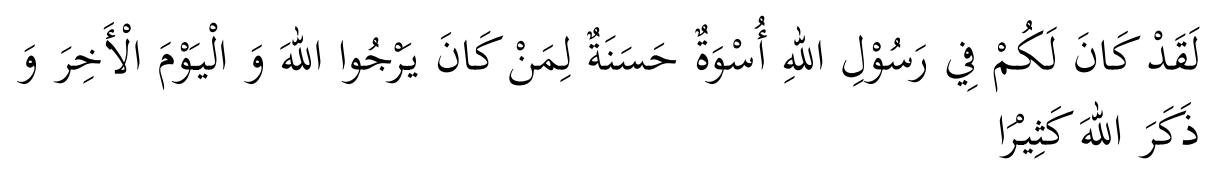

Artinya: Sesungguhnya Telah ada pada (diri) Rasulullah itu suri teladan yang baik bagimu (yaitu) bagi orang yang mengharap (rahmat) Allah dan (kedatangan) hari kiamat dan dia banyak menyebut Allah. (Q.S. Al-Ahzab (33) : 21). 


\section{Fathimah Nur Shabrina}

Kedua ayat di atas menerangkan bahwa Rasulullah Saw merupakan teladan keluhuran akhlak. Hal itu merupakan anugrah yang Allah berikan kepada Rasulullah Saw sebagai teladan untuk ditiru oleh para pengikutnya.

Guru merupakan ujung tombak pendidikan. Sebagai ujung tombak, guru dituntut untuk memiliki kemampuan dasar yang diperlukan sebagai pendidik, pembimbing,dan pengajar. Kemampuan tersebut tercermin pada kompetensi guru. Kemerosotan moral para siswa seringkali dianggap karena kegagalan para guru dalam mendidik dan memberikan suri tauladan. Bila guru dahulu berarti orang yang yang berilmu, arif, dan bijaksana, kini guru dilihat tidak lebih sebagai fungsionaris pendidikan yang mengajar atas dasar kualifikasi keilmuan dan akademis tertentu. Faktor-faktor lain seperti kearifan dan kebijaksanaan yang merupakan sikap dan tingkah laku moral tidak lagi signifikan, sebaliknya dalam konsep klasik, faktor moral berada di kualifikasi pertama, sedangkan faktor keilmuan dan akademis berada di bawah kualifikasi moral (Azra, 1998: 165).

Sebagai guru yang bertugas menanamkan nilai-nilai keagamaan kepada siswa, sudah sepatutnya guru Pendidikan Agama Islam mempunyai kepribadian yang matang, yang dapat memberikan teladan bagi siswa dalam berperilaku. Akan tetapi, bukan berarti guru bidang studi lain tidak bertanggung jawab dalam pembentukan pribadi peserta didik, semua guru dan diharapkan dapat bersinergi dalam pembentukan akhlak siswa. Sentuhan guru di sekolah diharapkan mampu menciptakan sumber daya manusia yang berkualitas, baik secara keilmuan (akademis), maupun secara sikap mental. Dengan guru yang mempunyai kepribadian yang stabil, dewasa, disiplin, arif, berwibawa, teladan, dan berakhlak mulia, diharapkan dapat menciptakan peserta didik yang berkarakter dan berakhlak mulia sesuai dengan tujuan pendidikan.

Sekolah Islamic Village adalah sekolah Islam Terpadu yang menggunakan sistem belajar yang bernuansa Islami dan memiliki fasilitas boarding. Sekolah Islamic Village ini memiliki jenjang untuk Toodlers/PG/TK, Sekolah Dasar (SD), Sekolah Menengah Pertama (SMP), dan Sekolah Menengah Atas (SMA), Sekolah Menengah Kejuruan (SMK), hingga Sekolah Menengah Kejuruan Khusus Penerbangan. Sekolah Islamic Village ini telah memiliki program kerja terkhusus untuk pendidik, yang dimana mereka telah diajarkan untuk membangun karakter (character building) yang sudah berlangsung sejak tahun 2000 hingga sekarang. Sekolah Islamic Village sebagai lembaga pendidikan bertujuan membentuk lulusan-lulusan yang mampu berperan dalam kehidupan sosial dan budaya 
dengan didasari akhlak yang mulia baik untuk lingkup Indonesia maupun internasional, mampu menjadi pemimpin yang tangkas dan cerdas dengan slogannya yaitu: sukses mulia dengan iman, ilmu, dan akhlak.

Bertitik tolak dari latar belakang masalah diatas, maka peneliti tertarik untuk membahas dan menelitinya dalam bentuk artikel ilmiah. Adapun tujuan dari penelitian ini adalah untuk mengetahui ada atau tidaknya perbedaan antara kompetensi kepribadian guru agama Islam dan guru PKn dengan guru umum dalam membina character building yang berbasis pendidikan nilai-nilai islami di SMA Islamic Village Tangerang, Banten.

\section{METODE PENELITIAN}

\section{Jenis dan Pendekatan Penelitian}

Penelitian ini merupakan jenis penelitian kuantitatif. Metode penelitian yang digunakan adalah metode kuantitatif, karena data penelitian berupa angka-angka dan analisi menggunakan statistik.

Adapun penelitian ini termasuk jenis penelitian non eksperimen. Metode ini digunakan oleh peneliti untuk dapat mengetahui adanya komparasi antar kompetensi kepribadian guru agama Islam dan guru PKn dengan guru umum dalam membina character building yang berbasis pendidikan nilai-nilai islami di SMA Islamic Village Tangerang, Banten.

\section{Subjek dan Objek Penelitian}

\section{a. Subjek Penelitian}

Subjek penelitian adalah orang, tempat, atau benda yang diamati dalam rangka pembumbutan sebagai sasaran. Adapun subjek penelitia ini, adalah seluruh guru yang ada di SMA Islamic Village Tangerang, Banten, maka subjek inilah yang disebut dengan responden.

Penelitian ini yang berjumlah guru agama Islam dan guru PKn adalah sebanyak tujuh orang dan jumlah guru umum adalah sebanyak 29 orang. Oleh karena itu, teknik penentuan responden ini menggunakan type cluster. 


\section{Fathimah Nur Shabrina}

\section{b. Objek Penelitian}

Objek penelitian merupakan hal yang menjadi sasaran penelitian berupa himpunan elemen yang dapat berupa orang, organisasi atau barang yang akan diteliti yang menjadi pokok persoalan yang hendak diteliti untuk mendapatkan data secara lebih terarah. Adapun Objek penelitian dalam ini meliputi:

1. Kompetensi kepribadian guru.

2. Kualifikasi guru pendidikan agama Islam dan guru PKn dengan guru umum dalam pembinaan character building berbasis nilai-nilai islami.

\section{Lokasi Penelitian}

Penelitian ini yang akan dilaksanakan peneliti yaitu di SMA Islamic Village Tangerang, Banten. Terletak di Jalan Islamic Raya, Kelurahan Kelapa Dua, Kecamatan Kelapa Dua, Kabupaten Tangerang, Banten. Peneliti memilih tempat ini sebagai lokasi penelitian karena tempat ini memiliki ciri khas karakter terhadap guru-guru dan yang paling utama dikarenakan SMA Islamic Village ini sudah lama melakukan kegiatan pembinaan pembangunan karakter untuk para guru disana sejak tahun 2000 hingga sekarang (Raudha, wawancara personal, 2018). Oleh karena itu, di SMA Islamic Village Tangerang, Banten inilah kegiatan-kegiatan penelitian akan berlangsung.

\section{Identifikasi Variabel Penelitian}

Penelitian ini diambil dari variabel yang digunakan yang meliputi sampel bebas (sampel yang mempengaruhi atau menjadi penyebab bagi sampel lain) dan sampel terikat (sampel yang dipengaruhi atau disebabkan oleh pengaruh sampel lain), maka sampel-sampel dalam penelitian ini adalah:

1. Sampel bebas (Sampel $\mathrm{X}_{1}$, Independent): kompetensi kepribadian guru.

2. Sampel terikat (Sampel $X_{2}$, Dependent): kualifikasi guru pendidikan agama Islam dan guru PKn dengan guru umum.

\section{Populasi dan Sampel Penelitian}


Populasi adalah seluruh data yang menjadi perhatian kita dalam suatu ruang lingkup waktu yang kita tentukan. Sedangkan sampel adalah bagian dari populasi, sebagai contoh yang diambil dengan menggunakan cara-cara tertentu atau dapat juga diartikan sebagian wakil dari polulasi yang diteliti (Margono, 2007: 18-121). Adapun yang menjadi populasi dalam penelitian ini adalah seluruh guru di SMA Islamic Village Tangerang, Banten yang berjumlah 36 orang. Namun, dalam penelitian ini peneliti tidak menggunakan sampel penelitian, dikarenakan seluruh subjek penelitian (responden) yang diambil adalah jumlah keseluruhan guru-guru yang berada di SMA Islamic Village Tangerang, Banten. Dengan hal ini, adanya pembagian subjek penelitian yaitu guru khusus (guru agama dan guru PKN) yang berjumlah 5 orang dan guru umum yang berjumlah 26 orang.

\section{Instrumen dan Teknik Pengumpulan Data}

Adapun teknik pengumpulan data yang penulis gunakan adalah:

1. Angket atau Kuesioner

Angket atau kuesioner adalah suatu daftar yang berisikan rangkaian pertanyaan mengenai suatu masalah atau bidang yang akan diteliti (Nurboko dan Ahmadi: 76). Angket ini diberikan kepada seluruh guru di SMA Islamic Village Tangerang, Banten untuk mendapatkan informasi tentang komparasi antar kompetensi kepribadian guru khusus (guru agama Islam dan guru PKn) dengan guru umum dalam membina character building yang berbasis pendidikan nilai-nilai Islami di SMA Islamic Village Tangerang, Banten.

Adapun kisi-kisi instrumen penelitian ini sebagai berikut:

\section{Tabel 1}

\section{Kisi-kisi Instrumen}

\section{Kompetensi Kepribadian Guru}


Fathimah Nur Shabrina

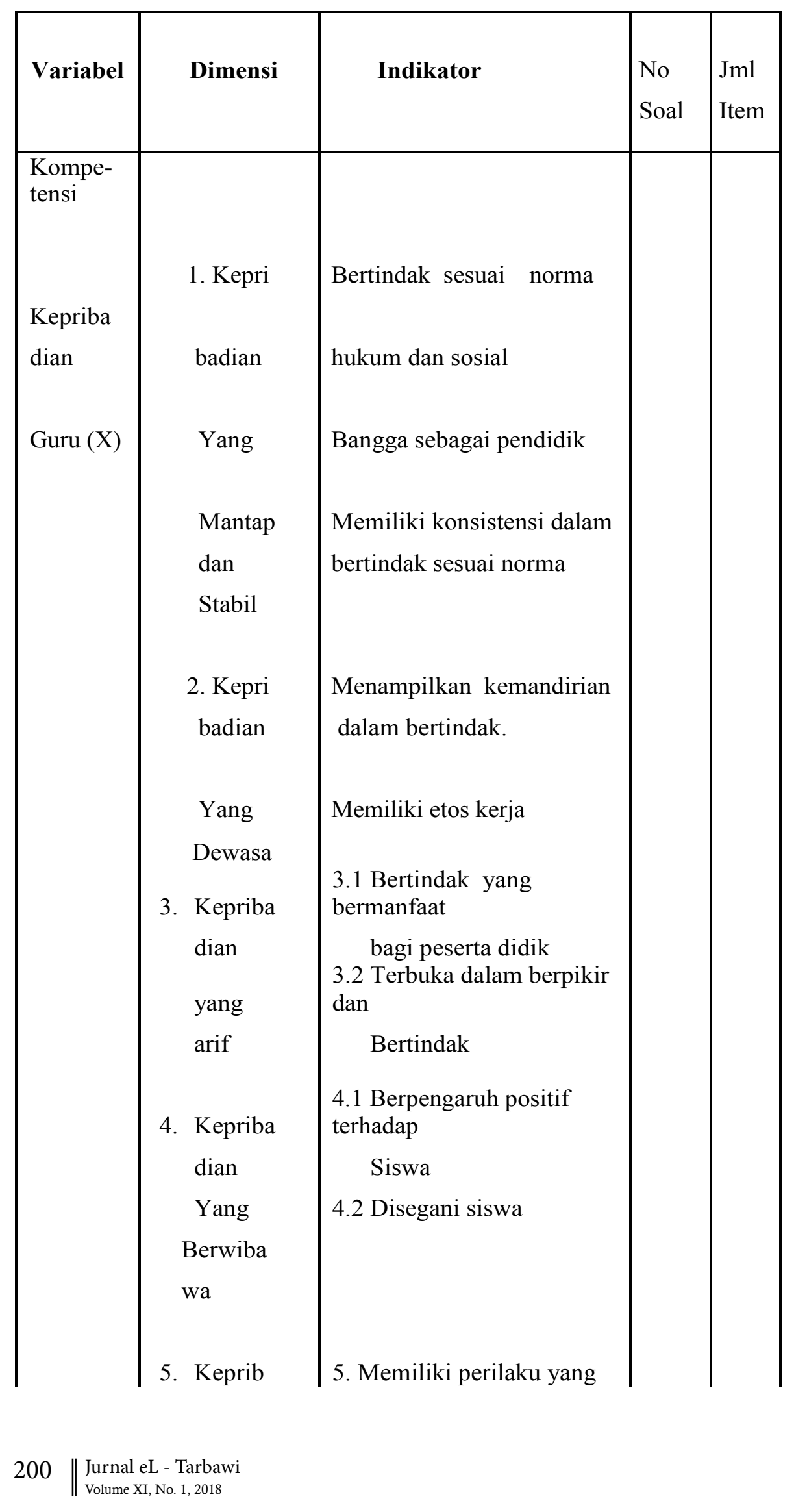




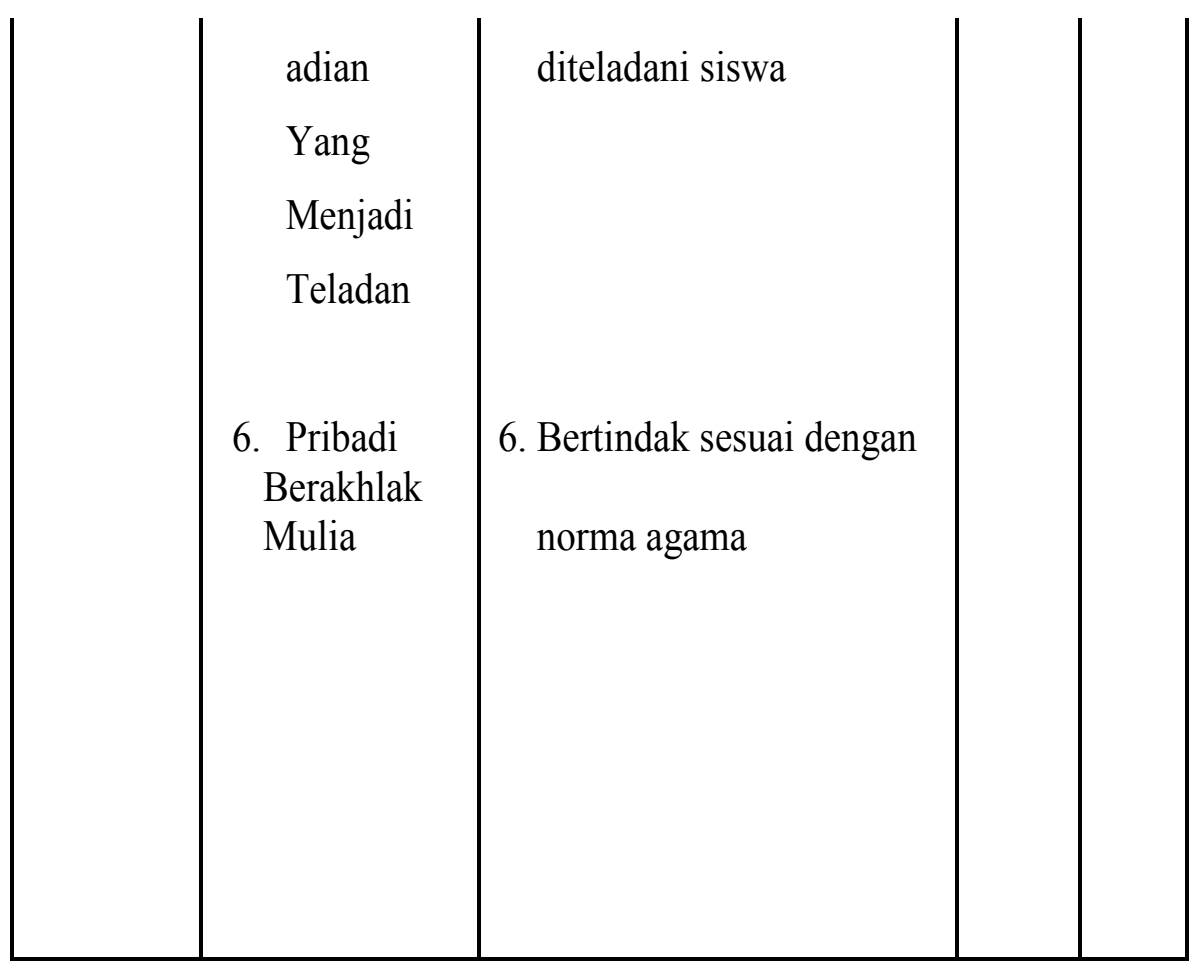

\section{Uji Persyaratan Instrumen}

\section{Uji Validitas}

Validitas berasal dari kata validity yang mempunyai arti sejauh mana ketepatan dan kecermatan atau alat ukur dalam melakukan fungsi ukurnya. Suatu skala atau instrument pengukur dapat dikatakan mempunyai validitas yang tinggi apabila instrument tersebut menjalankan fungsi ukurnya, atau memberikan hasil ukur yang sesuai dengan maksud yang dilakukannya pengukuran tersebut. Sedangkan tes yang memiliki validitas rendah akan menghasilkan data yang tidak relevan dengan tujuan pengukuran.

Dari hasil perhitungan akan didapat suatu koefisien korelasi yang digunakan untuk mengukur tingkat validitas suatu item dan untuk menentukan apakah suatu item layak digunakan atau tidak. Dalam penentuan layak atau tidaknya suatu item yang akan digunakan, biasanya dilakukan uji signifikansi koefisien korelasi pada taraf signifikansi 0,05 , artinya suatu item dianggap valid jika berkorelasi signifikan terhadap skor total.

Untuk melakukan uji validitas instrument ini dengan skala likert dan program SPSS. 


\section{Fathimah Nur Shabrina}

Menurut Sugiyono, Skala Likert digunakan untuk mengukur sikap, pendapat, dan persepsi seseorang atau sekelompok orang tentang fenomenasosial. Skor dalam intrumen ini antara lain:

\section{Tabel 2}

\section{Skor dalam Instrumen yang Menggunakan Skala Likert Positif (Favourable)}
a. Sangat setuju (SS)
: Skor 5
b. Setuju (S)
: Skor 4
c. $\quad$ Netral (N)
: Skor 3
d. Tidak Setuju (TS)
: Skor 2
e. Sangat Tidak Setuju (STS) : Skor 1

Dalam penelitian ini teknik yang digunakan untuk mengetahui kesalahan atau instrument adalah teknik korelasi product moment sebagai berikut:

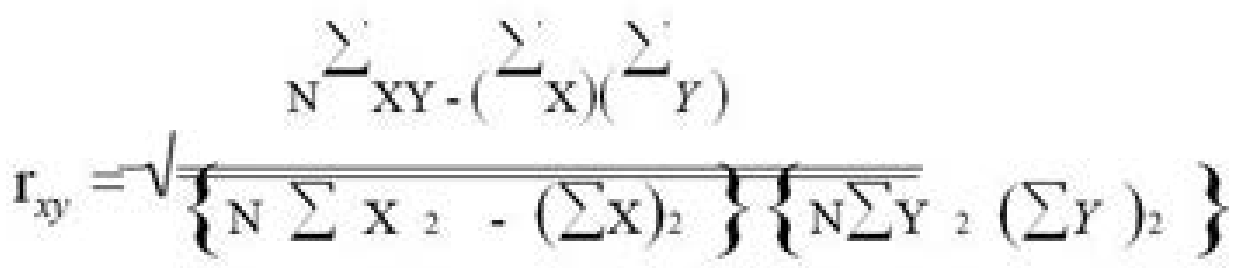

Sumber: Sudjana (2005: 72)

Keterangan : $\mathrm{r}_{\mathrm{xy}}=$ Koefisien korelasi antara variable $\mathrm{X}$ dan $\mathrm{Y} \mathrm{N}=$ Jumlah subyek, $\mathrm{X}$ $=$ Skor dari tiap-tiap item, dan $\mathrm{Y}=$ Jumlah dari skor item

Dengan kriteria pengujian apabila $r_{\text {hitung }}>r_{\text {tabel }}$ dengan 0,05 maka alat ukur tersebut dinyatakan valid, dan sebaliknya apabila $\mathrm{r}_{\text {hitung }}<\mathrm{r}_{\text {tabel }}$ maka alat ukur tersebut adalah tidak valid. Uji validitas dalam penelitian ini dilakukan dengan menggunakan program SPSS 20.0 for windows. 


\section{Studi Komparasi Kepribadian ...

\section{Uji Realibilitas}

Uji realibilitas menunjukkan sejauh mana instrumen dapat memberikan hasil pengukuran yang konsisten apabila pengukuran dilakukan berulang-ulang. Pengukuran reliabilitas tersebut dilakukan dengan menggunakan rumus alpha cronbach, dengan rumus:

$$
\mathrm{r}_{11}=\left[\frac{\mathrm{K}}{\mathrm{K}-1}\right]\left[1-\frac{\sum \sigma_{\mathrm{b}}^{2}}{\sigma_{1}^{2}}\right]
$$

Keterangan: $R_{11}:$ reliabilitas instrumen

$$
\mathrm{K} \text { : banyaknya butir pertanyaan }
$$

atau butir soal $\sum \sigma_{\mathrm{b}}^{2}$ : jumlah varians butir

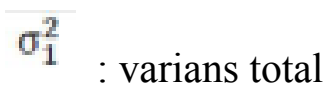

Kriteria uji reliabilitas dengan rumus alpha adalah apabila $r_{\text {hitung }}>$ $r_{\text {tabel }}$, maka alat ukur tersebut reliabel dan juga sebaliknya, jika $r_{\text {hitung }}<$ $\mathrm{r}_{\text {tabel }}$ maka alat ukur tidak reliabel. Dalam penelitian ini, dilakukan uji reliabilitas dengan menggunakan SPSS 24.0 for windows dengan model Alpha Cronbach's yang diukur berdasarkan skala Alpha Cronbach's 0 sampai 1 (Suharsimi, 2014: 319).

\section{Uji Asumsi}

\section{Uji Normalitas}

Data dari variabel penelitian diuji normalitas sebenarnya dengan menggunakan program SPSS for windows yaitu menggunakan teknik 


\section{Fathimah Nur Shabrina}

one-sample kolmogorov-smirnov test. Uji tersebut dimaksudkan untuk mengetahui normal atau tidaknya suatu distribusi variabel-variabel penelitian.

2. Uji Linieritas

Uji linieritas diperlukan untuk mengetahui linier tidaknya hubungan antara variabel bebas dengan variabel tergantung. Kaidah yang digunakan dalam penentuan sebaran normal atau tidaknya adalah jika $(\mathrm{p}<0.05)$ maka sebarannya dikatakan linier.

3. Uji Homogenitas

Uji homogenitas merupakan uji perbedan antara dua atau lebih populasi. Semua karakteristik populasi dapat bervariasi antara satu populasi dengan yang lain. Dua di antaranya adalah mean dan varian (selain itu masih ada bentuk distribusi, median, modus, range, dll).

\section{Teknik Analisis Data}

Teknik analisis data merupakan suatu cara yang digunakan untuk menguraikan keterangan-keterangan atau data tersebut dapat dipahami tidak hanya oleh peneliti, akan tetapi dapat dipahami oleh orang lain yang ingin mengetahui hasil penelitian.

Sesuai dengan tujuan penelitian yaitu mengetahui pengaruh dan seberapa besar komparasi antar kompetensi kepribadian guru agama Islam dan guru PKn dengan guru umum dalam membina character building yang berbasis pendidikan nilai-nilai islami di SMA Islamic Village Tangerang, Banten.

Kemudian untuk mengetahui ada tidaknya perbedaan, peneliti akan menggunakan rumus Independent Sample T-Test. Uji T-Test ini merupakan untuk mengetahui perbedaan rata-rata dua populasi/kelompok data yang independen. Adapun peneliti akan menggunakan bantuan software SPSS versi 20.0. Namun, pada uji T-Test independen ini memiliki asumsi atau syarat yang mesti dipenuhi, yaitu : 


\section{Studi Komparasi Kepribadian ...

a. Datanya berdistribusi normal.

b. Kedua kelompok data independen (bebas)

c. Variabel yang dihubungkan berbentuk numerik dan kategori (dengan hanya 2 kelompok).

Adapun rumusnya sebagai berikut :

$$
t_{\text {hit }}=\frac{M_{1}-M_{2}}{\sqrt{\frac{S S_{1}+S S_{2}}{n_{1}+n_{2}-2}\left(\frac{1}{n_{1}}+\frac{1}{n_{2}}\right)}}
$$

$$
\begin{array}{ll}
\text { Keterangan : M1 = rata-rata skor kelompok 1, M2 } & =\text { rata-rata skor } \\
\text { kelompok 2, SS1 = sum of square kelompok 1, SS2 } & =\text { sum of square } \\
\text { kelompok } 2, \mathrm{n} 1=\text { jumlah subjek/sample kelompok } 1 \text {, dan } \mathrm{n} 2 & =\text { jumlah }
\end{array}
$$$$
\text { subjek/sample kelompok } 2 .
$$

Selanjutnya, untuk menginterpretasikan t-test terlebih dahulu harus ditentukan, sebagai berikut:

1. Nilai signifikansi $\alpha$

2. Interval Confidence $=1-\alpha$

3. Df (degree of freedom), khusus untuk independent sample t-test atau DF (Degree of freedom).

4. Bandingkan nilai thit dengan ttab 


\section{Fathimah Nur Shabrina}

5. Apabila :

a. Berbeda secara signifikansi $\left(\mathrm{H}_{0}\right.$ ditolak $)$

b. Tidak berbeda secara signifikansi $\left(\mathrm{H}_{0}\right.$ diterima $)$

\section{HASIL PENELITIAN DAN PEMBAHASAN}

Tahapan Pelaksanaan Penelitian

\section{Tahap Persiapan}

Sebelum melakukan penelitian yang sesungguhnya, peneliti terlebih dahulu melakukan try out atau uji angket terhadap kuesioner yang akan digunakan untuk penelitian. Try out angket ini dilakukan tiga kali di tempat yang berbeda, try Out pertama dilakukan di SMA Citra Islami Tangerang, yang kedua di SMA Islamic Centre Tangerang, dan yang ketiga di SMA Islam Al-Azhar Bumi Serpong Damai (BSD) Tangerang Selatan. Try Out ini dilakukan untuk menguji validitas dan reliabilitas.

\section{Uji Try Out Instrumen}

\section{a) Uji Validitas}

Perhitungan validitas ini menggunakan SPSS versi 24.0 for windows dengan total keseluruhan responden 70 , yaitu 12 responden pada try out pertama, 26 reponden pada try out kedua, dan 32. Untuk uji validitas pada table "Corrected Item Total Correlation". Berikut ini table hasil pada Corected Item Total Correlation.

Tabel 3

\section{Try Out Uji Validitas Kompetensi Kepribadian Guru}


Studi Komparasi Kepribadian ...

\begin{tabular}{|c|c|c|c|}
\hline No. & ${ }^{\mathbf{r}}$ Hitung & ${ }^{\mathbf{r}}$ Tabel & Keterangan \\
\hline 1. & 0,328 & 0,2352 & Valid \\
\hline 2. & 0,046 & 0,2352 & Tidak Valid \\
\hline 3. & 0,508 & 0,2352 & Valid \\
\hline
\end{tabular}

\begin{tabular}{|c|c|c|c|}
\hline 4. & 0,131 & 0,2352 & Tidak Valid \\
\hline 5. & 0,179 & 0,2352 & Tidak Valid \\
\hline 6. & 0.525 & 0,2352 & Valid \\
\hline 7. & 0,508 & 0,2352 & Valid \\
\hline 8. & 0,634 & 0,2352 & Valid \\
\hline 9. & 0,678 & 0,2352 & Valid \\
\hline 10. & 0,482 & 0,2352 & Valid \\
\hline 11. & 0,497 & 0,2352 & Valid \\
\hline 12. & 0,619 & 0,2352 & Valid \\
\hline 13. & 0,536 & 0,2352 & Valid \\
\hline 14. & 0,382 & 0,2352 & Valid \\
\hline 15. & 0,607 & 0,2352 & Valid \\
\hline 16. & 0,808 & 0,2352 & Valid \\
\hline 17. & 0,473 & 0,2352 & Valid \\
\hline 18. & 0,699 & 0,2352 & Valid \\
\hline 19. & 0,639 & 0,2352 & Valid \\
\hline 20. & 0,392 & 0,2352 & Valid \\
\hline 21. & 0,645 & 0,2352 & Valid \\
\hline 22. & 0,546 & 0,2352 & Valid \\
\hline 23. & 0,392 & 0,2352 & Valid \\
\hline 24. & 0,667 & 0,2352 & Valid \\
\hline 25. & 0,596 & 0,2352 & Valid \\
\hline 26. & 0,586 & 0,2352 & Valid \\
\hline 27. & 0,461 & 0,2352 & Valid \\
\hline 28. & 0,509 & 0,2352 & Valid \\
\hline 29. & 0,630 & 0,2352 & Valid \\
\hline 30. & 0,626 & 0,2352 & Valid \\
\hline
\end{tabular}


Fathimah Nur Shabrina

\begin{tabular}{|c|c|c|c|}
31. & 0,597 & 0,2352 & Valid \\
\hline 32. & 0,450 & 0,2352 & Valid \\
\hline 33. & 0,514 & 0,2352 & Valid \\
\hline 34. & 0,585 & 0,2352 & Valid \\
\hline 35. & 0,618 & 0,2352 & Valid \\
\hline 36. & 0,599 & 0,2352 & Valid \\
\hline 37. & 0,712 & 0,2352 & Valid \\
\hline 38. & 0,507 & 0,2352 & Valid \\
\hline 39. & 0,620 & 0,2352 & Valid \\
\hline 40. & 0,632 & 0,2352 & Valid \\
\hline 41. & 0,750 & 0,2352 & Valid \\
\hline 42. & 0,608 & 0,2352 & Valid \\
\hline 43. & 0,532 & 0,2352 & Valid \\
\hline
\end{tabular}

Berdasarkan hasil yang dipaparkan dalam tabel diatas, maka konsistensi butir diketahui dengan cara analisis product moment dari pearson. Penentuan validitas berdasarkan $\mathrm{r}$ table pada taraf signifikansi $5 \%$ dengan jumlah $\mathrm{N} 70$ yaitu $\mathrm{df}=\mathrm{N}-2, \mathrm{df}=70-2=68 \mathrm{r}$ table 0,2352 . $\mathrm{N}$ merupakan jumlah responden yang dijadikan dalam try out angket. Jika butir pertanyaan kurang dari 0,2352 dinyatakan tidak valid atau gugur, begitu sebaliknya jika butir pernyataan lebih dari 0,2352 dinyatakan valid. Dari 43 butir pertanyaan terdapat 40 dinyatakan valid, sedangkan tiga butir pertanyaan dinyatakan tidak valid, tetapi indikatornya sudah terwakili, sehingga tiga butir pertanyaan yang gugur tidak perlu dipermasalahkan, jadi total jumlah pertanyaannya sebanyak 40 items dan 40 items tersebut yang akan digunakan untuk pengambilan data sesungguhnya.

b) Uji Reliabilitas

Uji reliabilitas digunakan untuk mengetahui konsistensi dari 
instrument sebagai alat ukur, sehingga dapat dipercaya. Suatu instrument dikatakan reliabel apabila pengukurannya konsisten dan akurat. Uji reliabelitas pada penelitian ini menggunakan koefisien alfa (a) dari Cronbach dengan bantuan SPSS versi 24.0 for windows.

Tabel 4

\section{Try Out Uji Reliabilitas Kompetensi Kepribadian Guru}

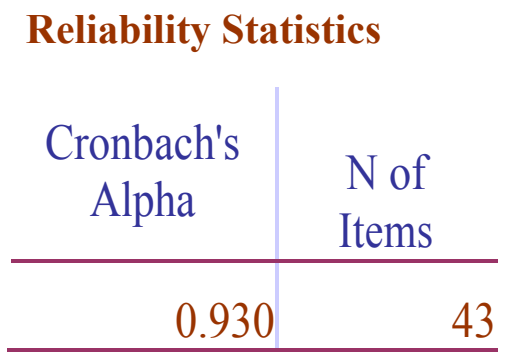

Berdasarkan hasil yang disajikan dalam tabel 4. Penentuan reliabilitas berdasarkan $\mathrm{r}$ Tabel pada taraf signifikansi 5\% dengan jumlah $\mathrm{N} 70$ yaitu $\mathrm{df}=\mathrm{N}-2, \mathrm{df}=70-2=68 \mathrm{r}$ tabel $0,930 . \mathrm{N}$ merupakan jumlah responden yang dijadikan dalam Try Out angket.

Hasil perhitungan analisis reliabilitas untuk kompetensi kepribadian guru agama Islam dan guru PKn dengan guru umum sebesar 0,930 pada kedua sampel ini dinyatakan reliabel.

\section{Tahap Pelaksanaan}

Tahapan selanjutnya yaitu pengambilan data penelitian yang dilakukan dengan cara penyebaran kuesioner kepada 36 responden untuk mendapatkan data tentang kompetensi kepribadian guru.

\section{Hasil Uji Prasyarat}

\section{Uji Asumsi}




\section{Fathimah Nur Shabrina}

\section{a. Uji Normalitas}

Uji normalitas digunakan untuk mengetahui apakah data berdistribusi normal atau tidak. Kaidah uji signifikansi dikatakan normal apabila $\mathrm{p}>0,05$.

Untuk uji normalitas menggunakan SPSS versi 24.0 for windows, maka hasil perhitungan didapat nilai kompetensi kepribadian guru agama Islam dan guru PKn dengan guru umum (X) mempunyai tingkat signifikansi sebesar 0,180 yang berarti lebih besar $>0,05$ ( $p$ $=0,180>0,05)$. Maka dapat dinyatakan bahwa distribusi data adalah normal.

\section{Tabel 5}

Try Out Uji Normalitas Kompetensi Kepribadian Guru Menurut Kolmogorov-Smirnov Test

\section{One-Sample Kolmogorov-Smirnov Test}

Unstandardized Residual

\begin{tabular}{llr}
\hline $\mathrm{N}$ & & 7 \\
\hline Normal & Mean & 0.0000000 \\
\cline { 2 - 3 } Parameters ${ }^{\mathrm{a}, \mathrm{b}}$ & $\mathrm{Std}$. & 16.73181655 \\
& Deviation & 0.257 \\
\hline Most Extreme & Absolute & 0.257 \\
\cline { 2 - 3 } Differences & Positive & -0.180 \\
\cline { 2 - 3 } & Negative & 0.257 \\
\hline Test Statistic & & 0.180 \\
\hline Asymp. Sig. (2-tailed) & \\
\hline
\end{tabular}
a. Test distribution is Normal.
b. Calculated from data.
c. Lilliefors Significance Correction. 
Tabel di atas menunjukkan bahwa data kedua sampel $\mathrm{X}_{1}$ dan $\mathrm{X}_{2}$ kompetensi kepribadian guru agama Islam dan guru PKn dengan guru umum yang memiliki tingkat signifikansi di atas 0,05 , yaitu $\mathrm{p}=0,180>0,05$ maka dapat disimpulkan bahwa kedua sampel tersebut adalah normal.

\section{b. Uji Linieritas}

Uji linieritas bertujuan untuk mengetahui apakah variabel mempunyai hubungan yang linier secara signifikan atau tidak. Data yang baik seharusnya terdapat hubungan yang linier antara variabel predictor $(\mathrm{X})$ dengan variabel kriterium (Y). Hasil analisis yang dilakukan dengan bantuan SPSS versi 24.0 for windows dihasilkan sebagai berikut:

\section{Tabel 6}

\section{Try Out Uji Linearitas Kompetensi Kepribadian Guru Agama Islam dan Guru PKn $\left(X_{1}\right)$ dengan Guru Umum $\left(\mathrm{X}_{2}\right)$}

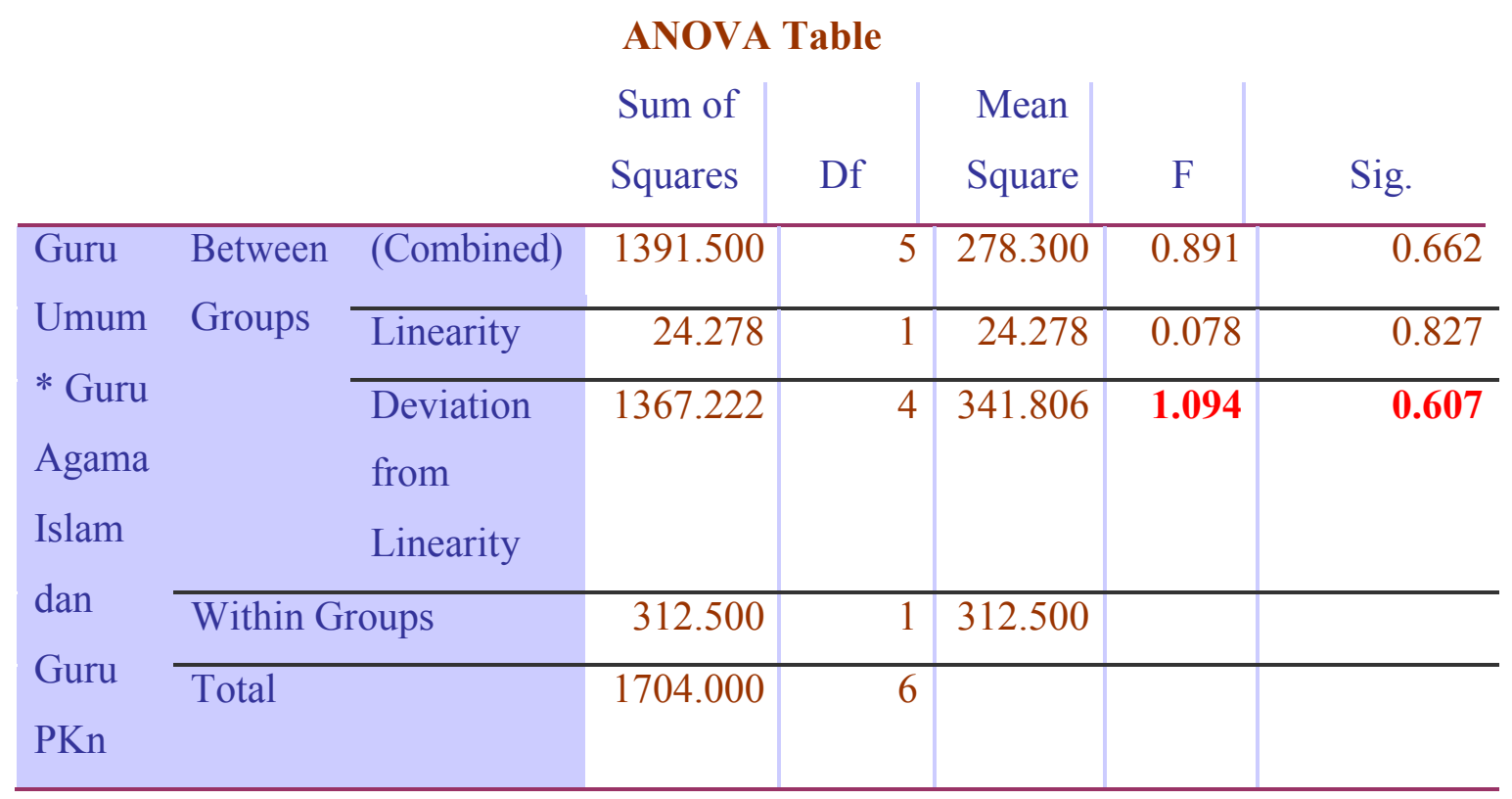




\section{Fathimah Nur Shabrina}

Hasil uji linieritas di atas menunjukkan bahwa deviation from linierity diperoleh $\mathrm{F}=1,094$ dan $\mathrm{p}=0,607$ $(\mathrm{p}>0,05)$. Berdasarkan data tersebut pada taraf signifikansi 5\% dapat disimpulkan bahwa data kompetensi kepribadian guru agama Islam dan guru PKn $\left(\mathrm{X}_{1}\right)$ dengan kompetensi kepribadian guru umum $\left(\mathrm{X}_{2}\right)$ terdapat hubungan yang linier.

\section{c. Uji Homogenitas}

Uji homogenitas dilakukan untuk memastikan setiap kategori data telah terpenuhi atau belum, jika uji homogenitas telah terpenuhi terbukti maka peneliti dapat melaksanakan tahap analisis data selanjutnya.

Tabel 7

Try Out Uji Homogenitas Kompetensi Kepribadian Guru Agama Islam

\section{dan Guru PKn $\left(X_{1}\right)$ dengan Guru Umum $\left(X_{2}\right)$}

Test of Homogeneity of Variances

Kompetensi Kepribadia

Levene

\begin{tabular}{rrrrr} 
Statistic & df1 & & df2 & Sig. \\
\hline 0.241 & & 1 & 34 & 0.627
\end{tabular}

Berdasarkan hasil uji homogenitas di atas, diketahui bahwa nilai signifikansi sebesar $0,627(\mathrm{p}=0,627>0,05)$ sehingga dapat disimpulkan bahwa data kompetensi kepribadian guru agama Islam dan guru PKn mempunyai varian yang tidak ada perbedaan dengan kompetensi kepribadian guru umum. 


\section{Uji Data Hasil Penelitian}

\section{Uji T-Test (Independent Sample Test)}

Uji T-Test ini memiliki tujuan untuk mempelajari perbandingan atau komparasi antar sampel lainnya. Adapun rumus Independent Sample Test sebagai berikut:

$$
t_{\text {hit }}=\frac{M_{1}-M_{2}}{\sqrt{\frac{S S_{1}+S S_{2}}{n_{1}+n_{2}-2}\left(\frac{1}{n_{1}}+\frac{1}{n_{2}}\right)}}
$$

Keterangan : $\mathrm{M}_{1}=$ rata-rata skor kelompok $1, \mathrm{M}_{2}=$ rata-rata skor kelompok $2, \mathrm{SS}_{1}=$ sum of square kelompok 1 , $\mathrm{SS}_{2}=$ sum of square kelompok $2, \mathrm{n}_{1}=$ jumlah subjek/sample kelompok 1, dan $\mathrm{n}_{2}=$ jumlah subjek/sample kelompok 2 .

Untuk sementara mengetahui nilai koefisien Independent Sample Test kita dapat mengacu pada tabel berikut:

\section{Tabel 8}

Hasil Uji T-Test (Independent Sample Test) Komparasi Kompetensi Kepribadian

\section{Guru Agama Islam dan Guru PKn $\left(X_{1}\right)$ dengan Guru Umum $\left(\mathbf{X}_{2}\right)$}




\section{Independent Samples Test}

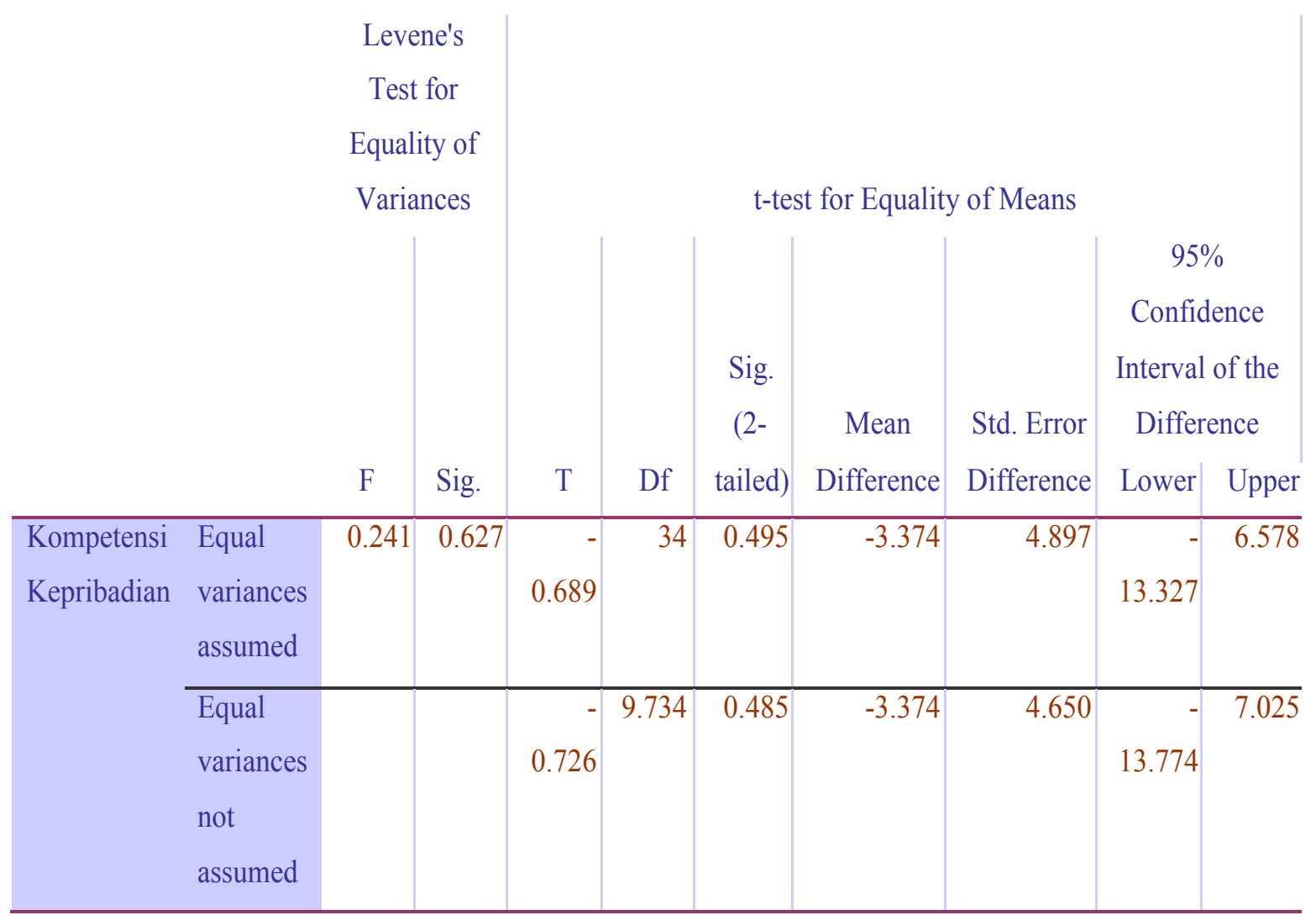

Tabel di atas menjelaskan nilai Sig. (2-tailed) yaitu sebesar 0,495 dan 0,485 , bahwadijelaskan besarnya persentase perbedaan variabel bebas terhadap variabel terikat pada Sig. (2-tailed) adalah lebih dari $0,05(p<0,05)$ yang mengandung pengertian bahwa terdapat perbedaan yang signifikan. Namun, hasil output memperlihatkan bahwa harga Sig. (2-tailed) melebihi dari 0,05 yaitu sebesar 0,495 dan 0,485 $(\mathrm{p}=0,495$ dan $\mathrm{p}=0,485>0,05)$. Berdasarkan data tersebut maka tidak ada perbedaan antara kompetensi kepribadian guru agama Islam dan Guru PKn dengan guru umum.

\section{Uji Hipotesis}


Berdasarkan tinjauan teoritis yang dikemukakan di atas, maka untuk menguji apakah ada komparasi antara kompetensi kepribadian guru agama Islam dan guru PKn dengan guru umum, maka diperlukan hipotesa sebagai berikut :

Ha : terdapat komparasi antara kompetensi kepribadian guru agama Islam dan guru PKn dengan guru umum.

Sementara itu untuk memastikan apakah T-Test tersebut signifikan atau tidak (dalam arti sample $X_{1}$ terdapat perbedaan dengan sample $\mathrm{X}_{2}$ ), hal ini dapat melakukan uji hipotesis ini dengan cara membandingkan nilai signifikan 2-tailed (Sig. 2-tailed) dengan probabilitas 0,05. Uji hipotesis membandingkan nilai Sig dengan 0,05 .

\section{Pembahasan Hasil Penelitian}

Penelitian ini berusaha menjawab permasalahan yang terjadi tentang ada atau tidaknya perbedaan antara kompetensi kepribadian guru agama Islam dan guru PKn dengan guru umum dalam membina character building yang berbasis pendidikan nilai-nilai Islami di SMA Islamic Village Tangerang, Banten. Setelah peneliti melakukan penelitian, terdapata 36 responden untuk mendapatkan hasil sekaligus menjawab rumusan masalah dalam penelitian ini yaitu Apakah ada perbedaan antar kompetensi kepribadian guru agama Islam dan PKn terhadap kompetensi kepribadian guru umum dalam membina character building yang berbasis pendidikan nilai-nilai Islami di SMA Islamic Village Tangerang, Banten.

Temuan hasil penelitian ini menunjukkan bahwa tidak ada perbedaan yang signifikan antara kedua sampel, yaitu kompetensi kepribadian guru agama Islam dan PKn $\left(\mathrm{X}_{1}\right)$ dan kompetensi kepribadian guru umum $\left(\mathrm{X}_{2}\right)$. Hal ini dibuktikan dari hasil analisis yang menggunakan Uji T-Test (Independent Sample Test) bahwa hasil nilai signifikansi 2-tailed. (Sig. 2-tailed) sebesar 0,495 dan 0,485 lebih besar dari probabilitas $0.05(\mathrm{p}=0,495$ dan 0,485 >0,05). Hasil tersebut dikuatkan juga oleh tidak adanya perbedaan mean kedua sampel, yaitu $X_{1}=6.578$ dan $X_{2}=7,025$. Berdasarkan hasil di atas menunjukkan bahwa antara kompetensi kepribadian guru 


\section{Fathimah Nur Shabrina}

agama Islam dan guru PKn dengan guru umum tidak memiliki perbedaan tanggung jawab dalam character building di SMA Islamic Village Tangerang, Banten.

Dari hasil di atas menunjukkan bahwa antara kompetensi kepribadian guru agama Islam dan guru PKn dengan guru umum tidak memiliki perbedaan tanggung jawab. Hal ini menjadi penting jika terjadinya penyimpangan karakter pada peserta didik tidaklah untuk menyalahkan guru agama Islam dan guru PKn, yang notabene nya pengetahuan mereka tentang pendidikan karakter yang baik lebih terkuasai, namun pada kenyataannya kedua-keduanya memilki tanggung jawab yang sama. Asumsi dengan guru agama Islam dan guru PKn yang lebih berfokus pada pengajaran nilai ternyata tidak berbeda dengan tanggung jawab guru umum. Tanggung jawab kompetensi kepribadian guru agama Islam dan guru PKn dengan guru umum adalah seimbang sama-sama sebagaiman yang dijelasakan dalam Undang-Undang No. 14 Tahun 2005 pasal 10 disebutkan bahwa:"guru harus memiliki kompetensi pedagogik, kompetensi kepribadian, kompetensi sosial, dan kompetensi profesional”.

Dengan demikian hipotesis alternative (Ha) yang berbunyi "terdapat komparasi antara kompetensi kepribadian guru agama Islam dan guru PKn dengan guru umum" ditolak. Serta menerima hipotesis nihil (Ho) yang berbunyi "tidak terdapat komparasi antara kompetensi kepribadian guru agama Islam dan guru PKn dengan guru umum".

\section{KESIMPULAN}

Berdasarkan hasil penelitian, analisis data dan pembahasan pada bab sebelumnya, peneliti berkesimpulan bahwa tidak ada perbedaan yang signifikan antara kedua sampel, yaitu kompetensi kepribadian guru agama Islam dan $\mathrm{PKn}\left(\mathrm{X}_{1}\right)$ dan kompetensi kepribadian guru umum $\left(\mathrm{X}_{2}\right)$. Hal ini dibuktikan dari hasil analisis yang menggunakan Uji T-Test (Independent Sample Test) bahwa hasil nilai signifikansi 2-tailed (Sig. 2-tailed) sebesar 0,495 dan 0,485 lebih besar dari probabilitas $0.05(\mathrm{p}=0,495$ dan 0,485 $>0,05)$. Hasil tersebut dikuatkan juga oleh tidak adanya perbedaan mean kedua sampel, yaitu $X_{1}=6.578$ dan $X_{2=} 7,025$. Dengan demikian, hal ini menunjukkan bahwa antara kompetensi kepribadian guru agama Islam dan guru PKn dengan guru umum tidak memiliki perbedaan tanggung jawab dalam character building di SMA Islamic Village Tangerang, Banten. 


\section{Studi Komparasi Kepribadian ...

\section{DAFTAR PUSTAKA}

Agustian, Ary Ginanjar. 2004. ESQ POWER: Sebuah Inner Journey Melalui AlIhsan. Jakarta: Penerbit Arga.

Amin, Muhammad Rusli. 2013. Rasulullah Sang Pendidik, Menyingkap Rahasia-Rahasia Pendidikan Karkater dari Sirah Nabi Muhammad SAW. Jakarta Selatan: AMP Press.

Arismantoro. 2008. Tinjauan Berbagai Aspek Character Building, Bagaimana Mendidik Anak Berkarakter?. Yogyakarta: Tiara Wacana.

Darajat, Zakiah. 2005. Kepibadian Guru. Jakarta: Bulan Bintang.

Dwiyanto, Djoko, dan Ign. Gatut Saksono. 2012. Pendidikan Karakter Berbasis Pancasila, Negara Pancasila: Agama atau Sekuler; Sosialis atau Kapitalis. Yogyakarta: Ampera Utama.

Hall, Hellen C. 2003. “Teacher's Attitude Toward Character Education and Inclusion in Family and Consumer Sciences Education Curriculum", dalam Journal of Family and Consumers Sciences Education, Vol. 21, No. 1.

Koesoema, Doni. 2007. Pendidikan Karakter: Strategi Mendidik Anak di Zaman Global, Jakarta: Gresindo.

Maemonah. Mei 2011. "Pendidikan Karakter dalam Mata Pelajaran Pendidikan Agama Islam di SMP 3 Pekalongan: Kajian atas Kurikulum dan Proses Pembelajaran" dalam Jurnal Penelitian Vol. 8, No. 1.

Mulyasa. 2007. Standar Kompetensi dan Sertifikasi Guru. Bandung: PT. Remaja Rosdakarya.

Nata, Abuddin. 2001. Perspektif Islam tentang Pola Hubungan Guru-Murid: Studi 
JuRnal penotdoran islam Fathimah Nur Shabrina

Pemikiran Tasawuf Al-Ghazali. Jakarta : PT. Raja Grafindo Persada.

Peraturan Pemerintah Nomor 19 Tahun 2005, Tentang Standar Nasional Pendidikan.

Stake, Robert E. 1994. "Case Studies”, dalam Norman K. Denzin \& Yvonna S. Lincoln (eds.).

Handbook of Qualitative Research. London: Sage Publications. 